\title{
Embedded Journalism Within the Framework of Changing Ownership Structure of the Media
}

\begin{abstract}
Hakan ALP
Istanbul University, Istanbul, Turkey

Inclination of capital groups - which realize widening impact field of media-to media sector due to relationships based on interests, and relationships/dilemmata between the governing parties and the capital owners have paved the way for a unilateral media structure not hearing the voice of others/local people. It is seen that the main stream media becomes more and more under direction of capital groups. Because of the effects created by the Second World War II, also war and media relation has gain different dimensions. Together with this differentiation, a new notion was born in the field of journalism during occupation period of the Iraq by the USA —Embedded Journalism. This notion, called as "embedded journalism" in English can be translated as "yapışmışlık—attachment", “gömülmüşlük—embeddedness", and "yamanmış—patched” in Turkish. In this connection, developments which have also been realized in the media economics in line with globalization process as seen all other aspects of life, changing of ownership structure in the media, and increase of concentrations, monopolization will be scrutinized in our study in addition how the fact of embedded journalism has affected the most important mission of journalism, objectivity within the framework of relations between journalism and government.

Keywords: media, globalization, embedded journalism, war, capital
\end{abstract}

\section{Introduction}

With coming of 1980s, as a result of increase in financial movements in the media sector due to effect of globalization in the world, we also observe an increase in concentration and monopolization in this sector. As the structure of the market has become monoblock and integrated, opportunity for making publications in benefit of society is getting harder day by day. Media has a key role in implementation and reproduction of neoliberal policies.

The ideological approaches popularized as undisputed myths by the media besides "consent and justification" required by the dominant ideology for continuance of its existence are obtained by the help of the media sector.

Against the reorganization of the media during globalization process, one of the points which must be taken into account most is what on the media turn a blind eye instead of things laid emphasis on by the media. The basic argument in the critics put forward against the media is generation of news contents in a way to improve the power held by the persons holding the economic, ideological, and politic power instead of giving objective, sufficient and correct information to the public - the most significant mission of the media, and having a multi dimensional but monophonic structure regarding its ownership structure.

Hakan ALP, Ph.D., Institute of Social Sciences, Istanbul University. 
With coming of 1990s, the media has become one of the irreplaceable fields of the international capital through intensive use of new communication technologies, giant holdings created by horizontal-vertical-cross monopolizations, and global compliance packages.

\section{Toutering of War Through Media}

Herman and Chomsky suggest that the media has quite ideological functions within the capitalist system; and it performs this function through teaching and infusing values, beliefs and behavior codes which have the individuals to integrate with the society they are living inside. They express that a systematic propaganda and disinformation is required in order to perform this role in today's societies, and the media fulfills the function of consent reproduction in favor of dominant classes:

The propaganda model focuses on the capital and power in equality, besides the effect of this inequality at different levels on the interests and preferences of media. It reflects on the ways used by the money and power holders to sieve news and select the ones appropriate for publishing, how the counter opinions are marginalized, how easily the government or dominant private interest groups are allowed to give their messages to the public. (Chomsky \& Herman, 1998, p. 22)

When the date became 11 September 2001, as expressed by Althuser, the media proved that it was the "ideological device" of the state once more. When we give a look to the ownership structure of the media toutering of war through an example, the existence reason of the media besides why and how it justifies the war will become easily understandable. When we examine the ownership structure of NBC, the fact that the General Electiric - the owner of NBC-also manufactures firearms is not a hidden truth. Naturally, each warlike broadcast made by this group lays barely the profit-making purpose of its owner.

Again, through the headlines of New York Post owned by Rupert Murdoch after September 11 attacks, it is possible to understand the attitude of media and line of news related to war are directly depended on the ownership structure, "Kill These Bastards" (12 September 2001), "This is War" (13 September 2001), "Wipe off the Map All States Harboring These Terrorists" (16 September 2001).

The fact of executives of huge media monopolies are also members of the boards of directors of companies such as Texaco, Shell, Exxon Mobil dealing with petroleum business in the Middle East is sufficient in explaining that the war in the region is related to the power on petroleum. Also, the statement "we" and "the other" causing generation of nationalist and racist policies were started to observe in the news reports.

Ann Coulter, in the New York Daily News dated 12 September 2001, said,

There is no time to locate the individuals involved in this terrorist attack... We should invade their countries, kill their leaders and convert them to Christianity. We weren't punctilious about locating and punishing only Hitler and his top officers. We carpet-bombed German cities; we killed civilians. That's war. And this is war!

Let's try to explain the dimension of violence language and toutering of war through the examples given below.

In the editorial of the New York Times dated 13 September 2001, "their blood must be spilled. Not coming month, even not coming week, now! Who are these people? Who cares... Find their place. Drop bomb. And bomb once more the ruins, debris left!" Rich Lowry, in the Washington Post dated 13 September 2001,

America has roused to a righteous anger has always been a force for good. States that have been supporting, if not Osame Bin Laden, people like him need to feel pain. If we flatten part of Damascus and Tehran, that is part of solution.

Thomas Woodrow, in the Washington Post dated 14 September 2001, "Nuclear capabilities should be used 
against the bin Laden in the desert of Afghanistan. To do less would be the cowardice on the part of the USA and the current administration".

In addition, the television news has developed some certain characteristics to attract large number of audiences to network holders in development of media sensationalism traditions. In this context, the television news still carries both style and content of show production business including impressive theme musics, garish effects and materials selected and arranged for creating the highest impact on the audiences (Trend, 2008, p. 137).

Media companies are naturally in alliance with the firearms manufacturers as being the rings of the same economic chain. The alliance continues with advertisement dependency and managing partners (Adakl1, 2006, p. 128). The executives of media monopolies also take office in the boards of directors of the firearms and petroleum monopolies. The integration of media companies with the firearms and petroleum monopolies is not limited with advertisement relations and managing partners. Also a capital relationship is established between them. For example, the General Electric, which was established for manufacture of electrical appliances in 1982 in the USA, also has activities in the fileds of banking, aerospace, war industries, and media.

The General Electric - the owner of NBC earned 9 billion dollars of its revenue of 54.5 billion dollars in 1989 from contracts of military articles. Most of the members of the General Electric's board of directors also participate in administration of large media companies such as Washington Post. They have close relationships with the USA government and the oil companies. In administration of $\mathrm{ABC}$ and $\mathrm{CBS}$ televisions, besides oil industry, also representatives of the defense and firearms industry. (Sazak, 2002, p. 168)

The General Electric was on the 5th rank in the listing of world's largest multinational corporations with a sales figure of 111 billion 630 million dollars in 2000 while it was on the 6th rank with the figure of 168 billion 307 million dollars in 2007. The media group NBC within the General Electric was merged with France origin media giant, Vivendi Universal Entertainment in 2004 and has become the 4th largest media group in the world. 80 percent of shares of the NBC Universal formed by the merger belong to the General Electric while remaining 20 percent belongs to the Vivendi. NBC Universal is consisted of 9 satellite channels, 29 television channels, 5 important amusement parks, and production companies owned by the Universal.

The General Electric - the majority shareholder of the NBC Universal - is also the largest manufacturer of firearms used by the American army. Patriot, Tomahawk, Cruise missiles, AWACS aircrafts, spy satellite systems are manufactured by companies of the General Electric. In this case, when the reporters and commentators working in medias of the NBC Universal within the General Electiric acclaim features of American firearms, and when they say that everybody should be sure that an army using these firearms will win a victory, indeed they propagandize firearms manufactured by the company which give their salaries.

Militancy of the dominant media has an economic, politic and cultural foundation as summarized above. In a society where the war and firearms industry has become the main economic sector, and where the media corporations integrated with firearms monopolies and other monopolies, it cannot be expected that the media will emphasis culture of peace. On the contrary, the media justifies the war and as the fourth power of war, shoulders the psychological war load (Yıldırım, 2010, p. 78).

Keeping of the global media ownership - which look ways for establishing dominancy all over the world and embrace publishing/broadcasting policies accordingly-by handful giant holdings has prevent democratic communications, and cause gnawing of public spheres by private interests (Duran, 2001, p. 14). 
Tim Russert, one of the reporters of NBC wore a necktie in the form of American flag during the interview he was conducting with the Vice President Dick Cheney just after start of Iraq attacks. Washington Post reporter, Howard Kurtz who could not associate this attitude of his colleague with occupational ethics wrote: "It is so important in such a crisis that the journalists not become a cheerleader with a flag in hand for the American team" (T1lıç, 2002, pp. 29-38).

\section{Journalist Identity and Embedded Journalism}

The notion of embedded journalism was first developed during occupation period of the Iraq by the USA by Victoria Clarke, the Pentagon spokesman and the Deputy Secretary of Defense and her consultants. The approving name for the "Embedded journalism" formula was the keenest names of the American government, Donald Rumsfeld - the Secretary of Defense.

The USA was called the embedded candidates, who would like to follow the second Iraq operation, to military camps starting from Novenmer-December 2003, and these reporters trained for minimum 2 and maximum 3 months. The reporters had spent their 24 hours in American military camps, and they trained on media subjects besides firearms technology. Namely, they were prepared for embedded reporting in terms of politics, ideology, and profession (Duran, 2003).

It was a requirement to agree on and sign the terms and conditions given in the contract generated by the department by each journalist to participate in the war as embeded. In this contract, the United States Department of Defense emphasized that it would be beneficial for both the government and the media corporation to embed "chosen" media employees in the "chosen" military units to provide following up of military operations by the media before, during, and after the war. Namely, they accept abiding by the administration, directives and regulations of the government. In case the media employees do not respect to the administration, directives, regulations, and regional rules, the "embedding" process will cease. In participation in the "embedding" process, if the person claim any right or demand whatsoever in case of any material loss or damage or personal injury which may occur, and in case of death of any person-even though this was caused or contributed by the government, he/she has to accept to reach a settlement with the government, pay indemnity and hold harmless the government.

Embedded journalists had to sign the "Embedded Journalism" Contract and the Protocol, and abide by the relevant rules. The accreditations of the persons who did not sign or respect these rules were instantly canceled. Some titles from this protocol:

This is for establishment of media relationship of the Defense Department together with the air force, naval force and army force with minimum restriction. Media operations include shaping of the public understanding, in the broadest sense, within the framework of national security both in present and in future. Our aim is to provide true information before other disinformation. During operations of the American army, the embedded journalists shall live, work and travel as part of the military unit. For safety of the operations, army public affairs officers and commanders shall work together with media.

Any information regarding fighting and war shall be provided to the media whenever possible. The mediamay stay with the unit they embeded for weeks, even for months under the said conditions. Reporters are not allowed to use their own vehicles while they are acting together with the USA army units. The unit shall supply any kind of help to the journalist. When normal communications become difficult, the reporters may utilize military amenities. There is no restriction for equipment for the reporters. However commanders shall 
stop broadcasting when they see it inappropriate in terms of security. The media employees shall be sent back if they have difficulty in keeping up with war conditions. All interviews to be conducted with the military personnel shall be recorded. For security of operations, an embargo shall be applied to some news. The embargo shall be cancelled after the security reason disappears. Necessary equipment against any potential biological, chemical or nuclear attack is distributed to the reporters. However, the cost is partially borne by the army and partially by the media corporation. Without approval of the commander, no flashlight or tv spotlight is used.

As the below mentioned news, information and broadcasts shall put in danger the operation security, they cannot be broadcasted until operation is done. The number of military units, important munitions, names of the military units, their geographical locations, potential operations in the future, security measures in the units, photographs of the dead or injured American soldiers, and their names cannot be given before 72 hours. Information regarding enemy soldiers captured in previous fighting can be given. Live broadcasts are allowed based on the situation. The commanders may apply embargo for security of the operations ${ }^{1}$ (Çubukçu, 2005, p. 145).

A research was conducted in the USA by PEJ (Project for Excellence in Journalism) in support of the Columbia University on news given by the embedded media members in the first 3 days of the Iraq war. Some findings from this research are:

No images regarding death of injury of Americans or Iraqi people were broadcasted in any embedded news. While 41 percent of the news was related to fighting, in half of this news (21 percent), other visual aspects of fighting were used. The outstanding images in 32 percent of the news were reflecting progress, maneuver of military units, bor their reconnaissance activities. In 15 percent of the news made by the embedded reporters, it was seen that they gave place to interviews they conducted with officers. And only 8 percent of this rate was opinions of the soldiers. (Özdemir, 2003, p. 259)

In examined news, it was determined that most of them were -6 from 10- were live broadcasting and not passed from editorial check, and in 8 news from 10, only the reporter was speaking. Today, while news is criticized for shallowness, and putting comment by the media, it has been determined that no killed people by shooting were showed in any of the news examined ${ }^{2}$.

According to the report prepared by BBC in relation to embedded journalism which was arisen as new branch of war reporting during occupation period of Iraq, the embedded journalists offered the news to their audiences by passing this news through a serious self-censorship process. According to this report, as the reporters of English televisions embedded to army were made a special effort for not showing bloody scenes, it was determined that the audiences felt as if they were watching a film instead of a real war because of such reporting type. While the reporters were giving news regarding who won or lost the fightings more of narrating a sports competition, the reaction of Iraqi people was distorted.

In the report, the fact that the embedded journalists preferred generally the Iraqi people welcomed warmly the coalition forces was especially emphasized. Also the following determination was made; the audiences perceived the war simpler and less dangerous than the reality due to this attitude of the journalists.

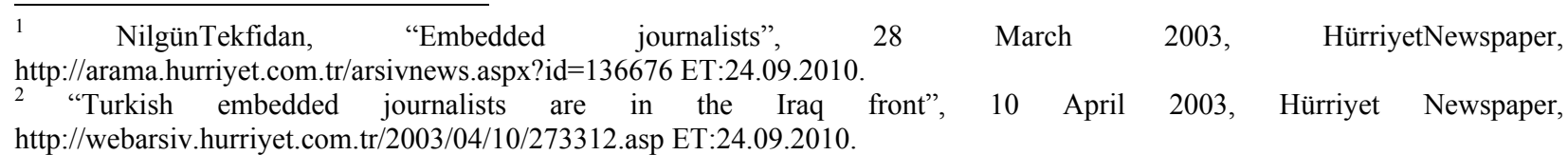
http://webarsiv.hurriyet.com.tr/2003/04/10/273312.asp ET:24.09.2010. 
While top executives of the BBC broadcasting corporation commented that this attitude of embedded journalists as an unjustness against the democracy, and they found that the quality of the briefings given by the coalition forces during the war was low at a level not to be expected in a pluralistic democracy ${ }^{3}$.

The position of Pentagon regarding the embedded journalism is very clear. According to Pentagon, when the success of operations and life safety of the soldiers are taken into account, the control of news to be given from the front is an essential prerequisite. The purpose in here is stated as not controlling of the news to be sent by the media, but successful completion of tasks undertaken by soldiers. However, conducting of this security control to be applied for news generation by top authorized military officers participated in the operations and have the journalists not respect the rules to leave the region are the indicators showing how the media has come to a dead-end during the embedding process.

At this stage, another important question to pay attention for people who consider optimistically the embedded journalism is if the war reporting will only be consisted of watching fighting/skirmish between the soldiers. If it is perceived as only to follow up the fighting between the soldiers or war strategies, and journalism is conducted in line with this perception, the people living the real destruction of war and their tragedy will be omitted. Such a news generation practice means undermining of the profession of journalism; and ignoring of vital values of a just basis such as public benefit, independency or compliance to ethics (Cangöz, 2008, p. 167).

\section{Conclusion}

While media is fulfilling its ideological functions on the basis of ownership structure, it also plays role of "gatekeeper" of the society by determining the agenda. The fact that the basic determinant and top filter on the media contents is the ideology explains the function of media in the hegemonic functioning of the neoliberal ideology. Also, the silence created by the media in determination of the agenda is another important dimension of its ideological function. By this way, speaking of the counter opinions are prevented, and a kind of wall protecting the system is created.

It is convenient to say that the international capital groups holding the mass media are not giving a good account in terms of neutrality and objectivity. Such capital groups, as complying with their class characteristics, both direct the society in line with their own interests and also they have a significant role in forming opinions of the substantial part of the society.

We see the reflections of the globalization and neoliberal policies in the field of media as monopolization, privatization and deregulation applications. Privatization and deregulation applications have a vital connection with the development and continuity of international capital. Because the privatization, during process of overcoming the crisis lived due to nature of capitalism, is the most critical part of both the globalization of capital by searching new areas in order to increase the profit rates and handing over process of the self-mechanism of the nation state and all arguments of economy to the international economic actors in lie with the neoliberal policies.

The ideological weapons of globalization, the media groups owned by international companies negatively affected the circulation of true and accurate news especially before and after the occupation period of Iraq, and they participated in, become a partner in disinformation campaigns made by the politic power holders for

\footnotetext{
3 "Embedded journalists did not reflect the war truly", 6 November 2003, NTVMSNBC, http://arsiv.ntvmsnbc.com/news/242657.asp.
} 
generally achieving a politic/economical purpose or they make disinformation for their own interests. We see that news contents which do not support the politic power holder and dominant power groups or have a counter attitude are censored by monopolized media groups.

The individual gets the information offered by the mass media to him/her within this unilateral news flow. This manipulated disinformation is the unique information he/she has (sense of reality), and his/her opinions and attitudes are guided in this way. By bombing some part of the society to the manipulated disinformation, the mass media plays a kind of leading role in creation of societies ready for adopting opinions.

The notion of investigation - the essential condition of journalism and reporting — was ignored in the examples of Iraq and Afghanistan, and cause effect relationship was completely removed. In addition, all world publics have become to ready to accept as true everything offered to them by the monopolized news agencies.

In general, the understanding of journalism and reporting exhibited by the American media during Iraq war to such dimension that the reporters, whose real task is submitting truths to the public, started to make news only in line with the announcements of the government spokesmen without making any research and investigation.

During Iraq war, the USA media agitated war and emphasized that war was inevitable. Any information given to the press by the USA government was accepted as true without questioning. The notion of investigation - the essential condition of journalism and reporting — was ignored and cause effect relationship was completely removed. In addition, the public has become to ready to accept as true everything offered to them by the monopolized news agencies.

Together with the embedded journalism contract considered in detail in this article, we see that censorship applications are made through controlling the media organs before broadcasts/publications.

Which events will be put in the news by the embedded journalists is determined through a previously signed contract. For example, it is forbidden to embeded journalists to levae the military units as we can see in the articles included to the protocol. The said reporters had to make news complying with the military view point of the USA during preparation of their news contents and presentation of the same.

When accepting participating in the "embedding" process, the media employees also acknowledged to be abided by the administration, directives and regulations of the government. The result of termination of "embedding" process due to violation of administration, directives, regulations and regional rules of the government by the media employee is a critical data revealing the fact that how elbow room of the media employees, who need to act boldly and objectively, has narrowed.

In our opinion, the war reporting practice should depend on giving information based on truths and data even though all negativity generated by the globalization and capital accumulation processes. Understanding of reporting should keep distance to personal opinions, belief, and judgments. Descriptions made during presentation of news contents should be objective.

\section{References}

Adaklı, G. (2006). Türkiye'deMedyaEndüstirisi (Media industry in Turkey). Ankara: Ütopya Publishing.

Büyükbaykal, C. (2008). The concentration of global media structure (KüreselMedyaYapılarınınYoğunlaşması). İstanbul ÜniversitesilletişimFakültesi Dergisi, 31, s.25-33

Cangöz, İ. (2008). UygunAdımMedya (Proper step media). Ankara: Ayraç Publishing.

Chomsky, N., \& Herman, E. (1998). MedyaHalkaNasllEvetDedirtir (How does media make people say yes). İstanbul: Minevra Publishing. 
Chomsky, N., \& Herman, E. (2004). MedyanınKamuoyuImalatı (The media's manufacture of public opinion). İstanbul: Nemesis Publishing.

Çubukçu, M. (2005). AteşAltınaGazetecilik (Journalism under fire). İstanbul: Metis Publishing.

Doğan, T. (2006). RizanınImalatı: Bir Propaganda AracıOlarakMedya (Manufacturing consent: Media as a propaganda tool). Retrieved from http://www.bgst.org/keab/ManufacturingConsent.asp

Duran, R. (2001). BurasıDünya Polis Radyosu/Global MedyaEleştirileri (Here is world police radio/Global media criticism). İstanbul: Yap1Kredi Publishing.

Duran, R. (2010). Embedded: IlliştirilmişDeğilAskeriYatıl (Embedded: Not embedded but military boarding). Retrieved from http://bianet.org/bianet/medya/18038-embedded-ilistirilmis-degil-askeri-yatili

HürriyetGazetesi, Türkembedded'leriIrakcephesinde" (Turkish embedded are at Iraq front). (2003). Retrieved from http://webarsiv.hurriyet.com.tr/2003/04/10/273312.asp

İnceoğlu, Y. (2006). Kitle İletişim Araştırmalarında Medya-İktidar İlişkilerinin Tarihsel Gelişimi (The historical development of media-power relationship on mass media researches). Retrieved from http://www.yasemininceoglu.com/guncel26.php

Özdemir, C. (2003). OnlarlaydimAmaOnlardanDegildim (I was with them but not one of them). İstanbul: Dogan Publishing.

RadikalNewspaper. (2003). ABD'deMedyaTekelleşmeYolunda (Media in USA is on the course to monopolization). Retrieved fromhttp://www.radikal.com.tr/haber.php?haberno=75114

Sazak, D. (2002). 11 EylülGölgesinde Saddam (Saddam in the shade of September 11). İstanbul: Dogan Publishing.

T11ı̧, D. (2002). Medya, SavaşveDemokrasi (Media, war and democracy). Karizma Dergisi, 9, 21-32.

Trend, D. (2008). MedyadaŞiddetEfsanesi (The violence myth on media). İstanbul: Yap1Kredi Publishing.

Yıldırım, R. (2010). DördüncüKuvvetMedya (The fourth force media). İstanbul: Karınca Publishing. 